\title{
Critical remarks of Cerastium subtetrandrum Murb.
}

\begin{abstract}
ADAM ZAJAC
Institute of Botany, Department of Taxonomy and Plant Phytogeography, Jagiellonian University
\end{abstract}

(Received: January 30, 1974.)

\begin{abstract}
After critical review of taxonomic characters of Cerastium subtertandrum Murb. the author proposes to reduce this taxon to the status of a form of Cerastium pumilum s.s.
\end{abstract}

\section{INTRODUCTION}

During a systematic revision of Polish species of the genus Cerastium of section Fugacia, particular attention was paid to Cerastium subtetrandrum Mrub. reported from Poland by Kulczyński (1921) and Szafer, Kulczyński and Pawłowski (1953). In the literature it was reported in two regions of Poland, namely the sea-shore of the Baltic and the Białowieża Forest. Unfortunately, neither the original sources were available for were specimens with characteristics corresponding to this taxon found in herbarium materials. Detailed observations of this taxon were made and this work contains a few suggestions concerning it.

\section{MATERIAL}

To make the observation of the characters of $C$. subtetrandrum easier comparative materials were borrowed from various herbaria: 8 sheets (107 specimens) from the herbaria of Gratz and Copenhagen and 6 sheets (32 specimens) from Polish herbaria (Table 1). All specimens of Gratz had been revised by Möschl (Nos. of revision 2015, 2014, 2017; the number of the fourth sheet was not noted). One sheet came from Herbarium Europeum published by Dr. Baenitz (No. 7165). It was collected by Murbeck in locus classicus C. subtetrandrum in South Scania between Limhann and Malmö (it is probably a double syntype). As the taxon is rather rare (Hulten 1950 gives 31 localities from Scandinavia) the quantity of materials may be 


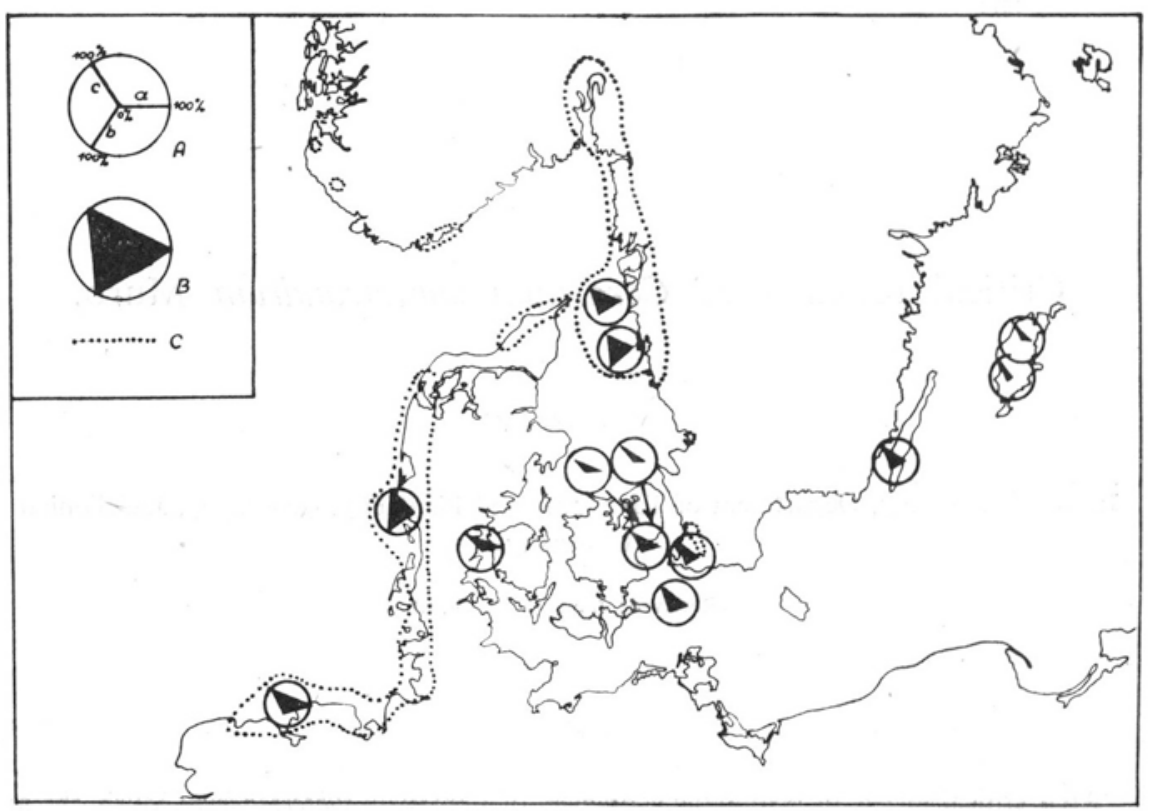

Fig. 1. Distribution of characters of Cerastium tetrandrum Curt. (\%) in populations of C. tetrandrum and $C$. pumilum Curt. subsp. pumilum $\mathrm{f}$. subtetrandrum Lange

A - empty circle, $100 \%$ of characters of $C$. pumilum subsp. pumilum f. pumilum: a - percentage of tetromerous flowers in population, $\mathrm{b}$ - percentage of examples with inflorescentes longer than the other part of stem, $\mathrm{c}-$ percentage of examples with pentamerous flowers in population; B - circle with black patch triangle in population, $100 \%$ characters of $C$.

tetrandrum; $\mathrm{C}-$ bound of $C$. tetrandrum range

estimated as sufficient. All more important centres of occurrence of the taxon are represented in the material (Fig. 1) namely the Danish islands Amager and Saltholm (so far the only localities known in Denmark), the island Aarö belonging to Schleswig-Holstein (Hukten 1950 and Christiansen 1953 do not give this locality), the above-mentioned locality from South Scania, the islands Ölnd and Gotland, as well as specimens from Burgerland (Austria).

\section{DISCUSSION}

The following characters distinguishing C. subtetrandrum from C. pumilum Curt. subsp. pumilum are given in the literature:

a. all bracts unscaricus (in C. pumilum subsp. pumilum at least the upper ones narrow membranes).

b. presence of a certain number of tetramerous flowers in C. tetrandrum.

c. size of seeds (C. subtetrandrum about $0.5 \mathrm{~mm}$ C. pumilum about $0.7 \mathrm{~mm}$ ).

d. petioles of fruit straight, while in C. pumilum subsp. pumilum slightly bent

e. sepals in C. subtetrandrum 7-9 $\mathrm{mm}$, fruit 7-10 $\mathrm{mm}$, while in C. pumilum subsp. pumilum sepals $4-5 \mathrm{~mm}$, fruit $6-8 \mathrm{~mm}$. 
The first of the characters should be examined on a larger scale also taking into consideration its occurrence in C. tetrandrum Curt. It is reported by Aschers on and Graebner (1919), Rothmaler $(1962,1966)$ Sell Witehead (1964 a), Weimarck (1963) for both C. subtetrandrum and C. tetrandrum, but only for the former species by Kulczyński (1921). The green bracts of C. subtetrandrum and C. tetrandrum are generally opposed to the unscarious bracts of $C$. pumilum s. 1 . with the reservation that in $C$. pumilum subsp. pumilum the lower bracts are also green. This character specified in many floras is not very good and not very easy to observe below the most significant doubts connected with it are discussed.

1. All species mentioned here have inflorescences of various sizes (the ratio of their length to the rest of the stem will be discussed later). The number of embranchments of inflorescences is not a taxonomic character. Thus within one species with considerably well-developed inflorescences (sometimes with six-or sevenfold embranchments) and poorly branched ones in which petioles of the upper flowers grow from the angles of the lowest bracts can be found. Besides these extreme forms there are all sorts of intermadiate ones. Therefore the differentiation of the discused species on the basis of their upper bracts is often impossible since they possess only one pair of bracts.

2. The lowest bracts in the discused taxon are almost always unscarious (with the exception of $C$. pumilum subsp. pumilum $f$. medium Möshl, where on one specimen both scarious and unscarious lowest bracts can be found), hairy, on both sides and similar to leaves, but the upper bracts, though their membrane is sometimes invisible, are hairy from the outside only and on the inside the epidermis is shiny, membraneous and nude. Therefore the desciption found in many floras that bracts are green and similar to leaves is inaccurate. Taking into account what was said above one can state that the difference between scarious and unscarious bracts is not clear and that all sorts of intermediate forms exist.

3. In three related taxons of the reviewed material, namely $C$. tetrandrum, $C$. subtetrandrum and $C$. pumilum subsp. pumilum a more or less distinct membrane was observed on the upper bracts. This character occurred in various degrees in populations of the same species. In C. tetrandrum it was relatively the most rare. Perhaps this is correlated with the fact that in this species inflorescences sometimes start at the very bottom of the stalk and this fact may cause the more pronounced and more frequent resemblance of bracts to leaves.

All the three aspects discussed above have led to the recognition of scarious upper bracts as a taxonomically uncertain character. On the basis of the work of Möschl (1936, 1938, 1951, 1964), author of many monographic studies on this group, on characters concerning the lower bracts are of taxonomic importance.

The second character mentioned - the presence of tetramerous flowers - also proved to be very variable. The quantity of tetramerous flowers was calculated in a C. subtetrandrum population (Table 1, localities 5-13). The number of specimens in the population with the given percentage of tetramerous flowers was examined as well as the total number of flowers in the population and the number of specimens which had inflorescences longer than the rest of the stem. In part of the examined 
populations some individuals without tetramerous flowers were found even though the material was very homogenous. This is probably correlated with the number of flowers on the specimen, and thus the greater or smaller probability of the appearance of the character. The percentage of tetramerous flowers varied from 0 to $100 \%$ on different specimens. The data presented in Table 1 were obtained from the available herbarium materials and due to the varying number of specimens are difficult to interpret statistically. For this reason the numbers of specimens in particular groups are given without any additional computations. The percentage of tetramerous flowers in the population of C. pumilum was counted for all Polish materials (Fig. 2).

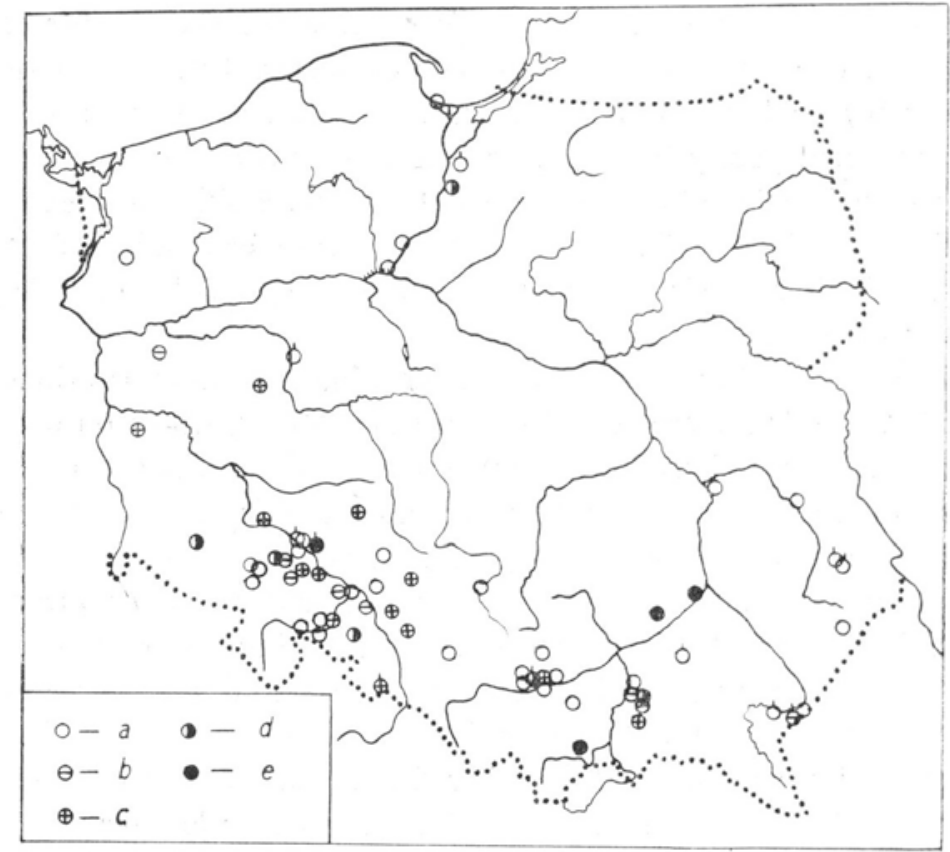

Fig. 2. Percentage of tetramerous flowers in Polish populations of Cerastium pumilum Curt. s. 1. $\mathrm{a}-0 \%$ of tetramerous flowers in population: $\mathrm{b}-$ less than $1 \%$ of tetramerous flowers in population; $\mathrm{c}-1 \%-5 \%$ of tetramerous flowers in population; $\mathrm{d}-5 \%-10 \%$ of tetramerous flowers in population; $\mathrm{e}-$ above $10 \%$ of tetramerous flowers in population (circle with mark — subsp. pumilum, circle without mark — subsp. pallens)

Tetramerous flowers were found not only in C. pumilum subsp. pumilum but also in C. pumilum subsp. pallens. Data concerning two populations which had the largest number of tetramerous flowers are given in Table 1. In comparison with population $5-15$ they have a greater number of specimens without tetramerous fowers (only specimens from locality 6, the Danish island Amager, have a similar number of such specimens). Thus the second of the characters distinguishing C. pumilum subsp. pumilum from Murbeck's C. subtetrandrum proved to be very variable with regard to the occurrence in individuals and in the population. Moreover, its parallel occurrence in both subspecies of $C$. pumilum also does not indicate its high taxonomic standing. 


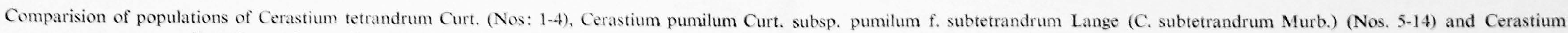
pumilum Curt. subsp. pallens (F. W. Schultz) Schinz et Thell. f. subtetrandroides Zaj. (Nos: 15-16) in respect of percent of Cerastium tetrandrum Curt. characters

\begin{tabular}{|c|c|c|c|c|c|c|c|c|c|c|c|c|c|c|c|c|}
\hline \multirow{2}{*}{ No. } & \multirow{2}{*}{ Locality } & \multicolumn{10}{|c|}{ Number of specimens of given percent of 4 -merous flowers } & \multirow{2}{*}{$\begin{array}{l}\text { Percent of } \\
\text { 4-merous flo- } \\
\text { wers in over } \\
\text { population }\end{array}$} & \multirow{2}{*}{$\begin{array}{l}\text { General } \\
\text { number } \\
\text { of specimens }\end{array}$} & \multirow{2}{*}{$\begin{array}{l}\text { Number of spe- } \\
\text { cimens without } \\
\text { 4-merous flowers }\end{array}$} & \multirow{2}{*}{$\begin{array}{l}\text { General number } \\
\text { of flower in } \\
\text { population }\end{array}$} & \multirow{2}{*}{$\begin{array}{l}\text { Percent of spe- } \\
\text { cimens about } \\
\text { inflorescent longer } \\
\text { than rest of stem }\end{array}$} \\
\hline & & $10 \%$ & $\begin{array}{l}10- \\
20 \%\end{array}$ & $\begin{array}{l}20- \\
30 \%\end{array}$ & $\begin{array}{l}30- \\
40 \%\end{array}$ & $\begin{array}{l}40- \\
50 \%\end{array}$ & $\begin{array}{l}50- \\
60 \%\end{array}$ & $\begin{array}{l}60- \\
70 \%\end{array}$ & $\begin{array}{l}70- \\
80 \%\end{array}$ & $\begin{array}{l}80- \\
90 \%\end{array}$ & $\begin{array}{l}90- \\
100 \%\end{array}$ & & & & & \\
\hline 1 & $\begin{array}{l}\text { Insel Norderney, } 11-12.5 .1895 \text {, Ig. W. } \\
\text { O. Focke, TRN }\end{array}$ & & & & & & & & & 1 & 6 & 97 & 7 & 0 & 35 & 36 \\
\hline 2 & $\begin{array}{l}\text { Dania, Zach. Jutlandia, peninsula } \\
\text { Skallingen, 4.7.1956, lg. J. Kornaś, } \\
\text { KRAM }\end{array}$ & & & 1 & 2 & 2 & 2 & 2 & 1 & 3 & 3 & 67 & 16 & 0 & 177 & 88 \\
\hline 3 & $\begin{array}{l}\text { Bohuslôh, Vinge et Buskér, 5. 1897, } \\
\text { lg. E. Th. et H. Fries, KRA }\end{array}$ & & 1 & 1 & 2 & 2 & 1 & & 2 & 1 & & 41 & 11 & 1 & 115 & 62 \\
\hline 4 & $\begin{array}{l}\text { insula Buskér, extra Gothoburgun, } \\
\text { 5. 6. 1856, lg. H. G. Lübeck, WRO }\end{array}$ & & & & 1 & 1 & 2 & & & & & 51 & 5 & 1 & 79 & 85 \\
\hline 5 & $\begin{array}{l}\text { Schleswig Holstein: Insel Aarö, } 6.1895 \\
\text { lg. Focke, TRN }\end{array}$ & & & & & & & & 2 & 1 & 2 & 83 & 5 & 0 & 24 & 0 \\
\hline 6 & $\begin{array}{l}\text { Amarger, Strandeng ved Kengeleendun, } \\
\text { 25. 5. } 1920,1 \text { g. K. Wiinstedt, C } \\
\end{array}$ & & 1 & 2 & & 2 & 2 & 3 & 1 & & 1 & 30 & 16 & 4 & 89 & 0 \\
\hline 7 & $\begin{array}{l}\text { Amager, Strandeng Syd for Drager, } \\
\text { 21. 5. 1925, lg. K. Wiinstedt, C }\end{array}$ & & & 2 & & 1 & 3 & 2 & & 1 & 1 & 55 & 10 & 0 & 48 & 0 \\
\hline 8 & $\begin{array}{l}\text { Amarger, Solled ved Kalvebod Strand, } \\
\text { 5. } 6.1884 \text {, lg. E. Rankior, C }\end{array}$ & 1 & & 4 & 1 & 2 & 3 & 2 & 1 & & & 46 & 14 & 0 & 220 & 15 \\
\hline 9 & $\begin{array}{l}\text { Danmark, insula Saltholm, 23.6.1898, } \\
\text { lg. C. Ostenfeld-Hansen, C }\end{array}$ & & & 1 & 1 & & 1 & 1 & & & & 43 & 4 & 0 & 148 & 39 \\
\hline 10 & $\begin{array}{l}\text { Scania, inter Limhamn et Malmö, } \\
4.6 .1887,4.6 .1891, \text { lg. Murbeck, WRO, } \\
\text { GZU }\end{array}$ & 1 & 4 & 1 & & & 1 & & & & & 18 & 7 & 0 & 243 & 36 \\
\hline 11 & $\begin{array}{l}\text { Olandia: Färgertaden, } 17.6 .1887, \\
\text { lg. L. J. Weboltedt, TRN }\end{array}$ & & 1 & 1 & & 1 & & 2 & & 1 & & 43 & 7 & 1 & 60 & 36 \\
\hline 12 & $\begin{array}{l}\text { Gotland: Ronehanm, 8. 6. 1898, } \\
\text { lg. K. Johansson, GZU }\end{array}$ & 3 & 2 & & & & & & & & & 10 & 5 & 0 & 200 & 20 \\
\hline 13 & $\begin{array}{l}\text { Gotland: Othern, 10. 5. 1894, } \\
\text { lg. M. Ostman, KRA }\end{array}$ & 1 & 1 & 2 & & & & & & & & 17 & 4 & 0 & 129 & 0 \\
\hline 14 & $\begin{array}{l}\text { Burgenland: Ufer einer Salzsee } \\
\text { Lacke bei St. Aussee, 27. 5. 1923, } \\
\text { lg. K. Rechinger, GZU }\end{array}$ & 4 & 8 & 4 & 6 & 6 & 3 & 1 & 1 & & & 20 & 51 & 18 & 401 & 9 \\
\hline 15 & $\begin{array}{l}\text { Polska, Sandomierz, Góry Pieprzowe, } \\
\text { 29. 5. 1968, lg. A. Zając, AZ }\end{array}$ & & 7 & 6 & 2 & & 4 & & 1 & & & 18 & 33 & 13 & 190 & 6 \\
\hline 16 & $\begin{array}{l}\text { Polska, Zachowice, distr. Wrockaw, } \\
\text { 1. 6. 1962, lg. J. Mądalski, JM }\end{array}$ & 4 & 5 & & & 1 & & & & & & 8 & 14 & 4 & 206 & 0 \\
\hline 17 & $\begin{array}{l}\text { Burgenland: Ad laemas salsas inter } \\
\text { Trauenkirchen et Podesdorf, } \\
\text { 30. 5. 1926, lg. K. Rechinger, GZU }\end{array}$ & & & & 1 & & 2 & 1 & 2 & & & 76 & 6 & 0 & 210 & 100 \\
\hline
\end{tabular}


The third of the characters given has no greater significance as populations of C. pumilum subsp. pumilum with seeds about $0.5 \mathrm{~mm}$ in dimension are frequently found (Zając unpubl).

Straight petioles mentioned as a character distinguishing C. subtetrandrum from C. pumilum subsp. pumilum are not observed in the examined material. Moreover, this character also occurs in C. tetrandrum.

Sell and Whitehead (1964 a) in addition give different dimensions of fruit and sepals for C. subtetrandrum and C. pumilum. This character, according to them, also distinguishes ${ }^{-} C$. subtetrandrum from $C$. tetrandrum, as the dimensions of the fruits and sepals of the latter are similar to those of C. pumilum. Measurements of the available material indicate that there is no basis for such a distinction of the dimensions of fruit and sepals in C. subtetrandrum as they correspond to the dimensions given for $C$. pumilum (for which the above-mentioned authors gave values which were too low).

On the basis of the lack of real differentiating characters between $C$. pumilum subsp. pumilum and C. subtetrandum it was decided to include the latter in the former with the rank of form. The specimens of subsp. pallens which had some tetramerous flowers were treated similarly, and distinguished as a new form, subtetrandriodes (Zając unpubl.)

There are several reason for this treatment of C. subtetrandrum. It shows the same variability as $C$. pumilum subsp. pumilum, a fact which has hitherto not been reported in the literature. In $C$. pumilum subsp. pumilum two forms were distinguished: $f$. pumilum and f. medium Möschl. f. pumilum has all bracts in the type of pumilum while f. medium has some bracts in the type of pumilum and some in the type of pallens Möschl (personal communication) believes that these are only biotopic modifications. In the material of $C$. subtetrandrum, the presence of specimens which corresponded to both forms was observed. The distribution of C. pumilum subsp. pumilum and $C$. subtetrandrum on the Scandinavian Peninsula (detailed distribution maps of these taxons exist for this area only) give further, though indirect, evidence. The ranges and even particular localities of both taxonomic units overlap almost entirely, with only a few insignificant exceptions (which may be explained by chance). Thus C. subtetrandrum occurs where $C$. pumilum in present. All areas from which $C$. subtetrandrum was reported so far, namely the Scandinavian Peninsula, Denmark. Poland, Lower Austria and Hungary, do not extend beyond the range of C. pumilum (Zając unpubl.)

The presence of tetramerous flowers in such different percentages may be possibly explained by penetrance of C. tetrandrum Curt. (general distribution - see Fig. 3). C. tetrandrum is the only specimen in this section which has tetramerous flowers (Table 1, localities 1-4), whose range of occurrence lies within that of C. pumilum. It differs from $C$. pumilum s. 1 . by the presence of high percentage of tetramerous flowers and also by the length of inflorescences which is greater than half the length of the whole plant while in C. pumilum s. 1 . the inflorescence makes shout $1 / 3$ of the specimen. For this study insufficient material of this species was used to state its taxonomic significance. In any case, only the two opposite sepals may show diffe- 


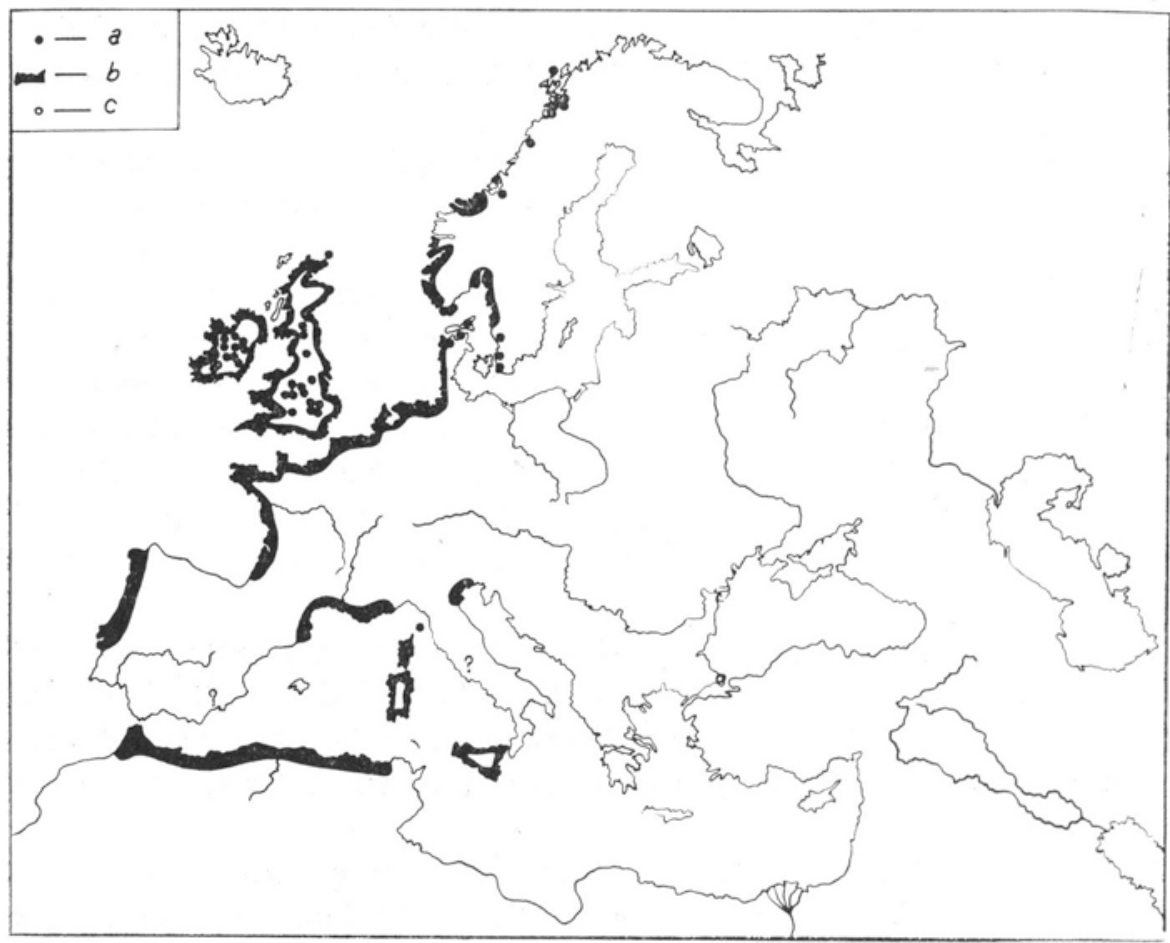

Fig. 3. General distribution of Cerastium tetrandrum Curt. (original)

a - distracted localities; $\mathrm{b}$ - consistence range; $\mathrm{c}$ - synanthropic locality

rentiating characters an the two others generally have a wide membrane comprising the whole sepal. In the literature no mention was found of the existence of hybrids between $C$. pumilum s. 1. and C. tetrandrum, from this group only $C$. glutinosum $\times C$. subtetrandrum (Murbeck 1898) is given. But considering its description it is rather a hybrid between $C$. glutinosum and C. tetrandrum or else it is a specimen similar to f. subtetrandroides.

In order to examine the distribution of the two characters (the third one was not suitable as $C$. pumilum $\mathrm{s}$. 1. shows a variable width of membrane and the eventual influence of $C$. tetrandrum is difficult to detect) their proportional participation in $C$. subtetrandrum and $C$. tetrandrum populations was counted and marked on a map (Fig. 1). The appropriate percentages were marked on the radii of circles. As the third character the percentage of specimens with tetramerous flowers in the population was chosem. Closed triangles indicate $100 \%$ of C. tetrandrum characters (note - according to the diagnosis species with all or almost all tetramerous flowers make up in C. tetrandrum), an open circle indicates $100 \%$ of features of C. pumilum. The range of $C$. tetrnadrum in this region was marked. The obtained picture is rather clear. Populations with a great predominance of $C$. tetrandrum characters are found only within its range of occurrence. In the vicinity of Malmö on the southern promontory of Scania (near insular localities of C. tetrandrum) the proportional 
occurrence of $C$. tetrandrum characters is greater than e.g. in Gotland. These taxons are closely related taxonomically (few differentiating characters and a considerable difference from other species of Leiopetala subsection). As can be seen from Fig. 1 and Table 1 penetrance also goes in the other direction as no population of C. tetrandrum showed $100 \%$ of characters of this taxon. The chromosome numbers of the species mentioned here are as follows: C. tetrandrum $2 \mathrm{n}=72$ (Blackburn, Morton 1957, Brett 1955), and $2 \mathrm{n}=36$ (Wulf 1937, Rohweder 1939). The same number $2 \mathrm{n}=72$ was found for $C$. subtetrandrum by Hagerup (1941) on material from Denmark. For C. pumilum subsp. pumilum $2 \mathrm{n}=72$ (Blackburn, Morton 1957), $2 \mathrm{n}=90$ (Brett 1952, 1955), Söllner (1954), 2n=95 (Brett 1952, 1955), 2n=94, 96 (Söllner 1954). Thus the two species appear to have $2 \mathrm{n}=72$, though in $C$. pumilum subsp. pumilum this is only one of the possibilities. Thus it is likely that the introgression of $C$. tetrandrum characters might affect only the part of $C$. pumilum subsp. pumilum population which has $2 \mathrm{n}=72$. It should be stressed that the dimensions of seeds of a part of the population of $C$. pumilum subsp. pumilum and in $C$. pumilum subsp. pallens and C. subtetrandrum have very similar dimensions (Zają c unpubl). The introgression is very probable, the more so that the characters of tetramerous flowers also occurs in C. pumilum subsp. pallens; however, its occurrence in areas where no C. tetrandrum specimens are present proves that we are dealing with a historical phenomenon.

It is thus necessary to reduce the status of $C$. subtetrandrum. It seems that a return to the conception of Lange (1887) which distinguishes it as C.pumilum s. s. f. subtetrandrum is correct.

The solution proposed by Soll and Whitehend (1964 a, b) who treat C. subtetrandrum and $C$. tetrandrum as subspecies of $C$. diffusum Pers (syn. C. tetrandrum Curt.) in not acceptable due to the taxonomic inequality of the taxons joined in one taxonomic unit. Besides them a species of C. gussonei Tod. ex Lojac., distantly related to them, was included in this unit of classification with the rank of subspecies.

The problem of $C$. subtetrandrum requires further investigations which must be undertaken on more material by cytologists and embryologists. Only a hypothesis of the origin of this taxon was put forward in the present study.

\section{REFERENCES}

Ascherson P. and Graebner P., 1919, Synopsis der Mitteleuropäischen Flora. 5(1). Leipzig. Blackburn K. B. and Morton J. K., 1957. The incidence of polyploidy in the Caryophyllaceae of Britain and Portugal, New Phytol. 56: $344-351$.

Brett O. E., 1952. Basic chromosome numbers in the Genus Cerastium, Nature 170: 251.

Brett O. E., 1955. Cyto-taxonomy of the genus Cerastium. I. Cytology, New Phytol. 54: 138-148. Christiansen W., 1953. Neue kritische Flora von Schleswig-Holstein, Rendsburg.

Hagerup O., 1941. Cerastium subtetrandrum Murb., Bot. Tidsk. 45 (4): 389.

Hulten E., 1950. Atlas över växternas utbredning i Norden, Stocholm.

Kulczyński S., 1921, Rodzina: Caryophyllaceae — Goździkowate, in Flora polska. 2: 147-244, Kraków. 
Mösch1 W., 1936. Uber einjährige europäische Arten der Gattung Cerastium (Orthodon-Fugacia-Leiopetala), Repert. Spec. nov. 41: 151-163.

Mösch1 W., 1938, Morphologie einjähriger europäischer Arten der Gattung Cerstium (Orthodon-Fugacia-Leiopetala), Östereich. bot. Zeitschr. 87: 249-272.

Möschl W., 1951, Cerastia Lusitaninae archipelagorumque "Acores" et "Macera", Agron. Lusit. 13 (1): $25-66$.

Mösch1 W., 1964. De Cerastiis Africae Septentrionalis. Mem. Soc. Brot. 17: 5-116.

Murbeck K., 1898, De nordeuropeiska formena af slägtet Cerastium, Bot. Notiser 1898: 241-268.

Rohweder H., 1939, Weitere Beiträge zur Systematik und Phylogenic der Caryophyllaceen, Beih. Bot. Centralbl. B. 59: 1-58.

Rothmaler W., 1962. Excursionsflora von Deutschland 2. Gefässpflanzen, Berlin.

Rothmaler W., 1966. Excursionsflora von Deutschland 4. Kritischer Ergänzungsband, Gefässpflanzen, Berlin.

Sell P. D. and Whitehead F. H., 1964 a. Cerastium L. (annual) 1:136-145, in Flora Europaee, Cambridge.

Sell P. D. and Whitehead F. H., 1964 b. Notes on the Annual Species of Cerastium in Europe, Feddes Repert. spec. nov. reg. veg. 69(1): $14-24$.

Söllner R., 1954, Recherches cytotaxonomiques sur le genre Cerastium, Ber. Schweiz Bot. Ges. 64: $221-354$.

Szafer W., Kulczyński S. and Pawłowski B., 1953. Rośliny polskie, Warszawa.

Weimarck H., 1963. Skanes flora, Lund.

Wulf H. D., 1937. Karyologische Untersuchungen an der Halophytenflora Schleswig - Holsteins, Jahrb. wiss. Bot. 84: 84:812-840.

Zając A., unpubl., The Genus Cerastium L. sections Ceaspitosa and Fugacia in Poland, Monograph Bot. ...

Author's address

Dr Adam Zając

Institute of Botany

Jagiellonian University

Lubicz Str. 46

30-436 Kraków, Poland

Krytyczne uwagi o Cerastium subtetrandrum Murb.

Streszczenie

W sekcji Fugacia rodzaju Cerastium L., zlikwidowano gatunek C. subtetrandrum Murb. przyznając mu tylko rangę formy w obrębie $C$. pumilum subsp. pumilum. Ten krok uzasadniono:

a. faktem, iż żadna z cech podanych dla $C$. subtetrandrum jako odróżniająca od C. pumilum subsp. pumilum nie okazała się stała dla tego taksonu (dotyczy to również okazów oznaczonych przez autora gatunku Murbecka i wybitnego specjalistę w tej grupie Möschla);

b. podobnym rozmieszczeniem lokalnym C. subtetrandrum i $C$. pumilum subsp. pumilum w Skandynawii (tj. na jedynym jak dotąd terenie, gdzie zostało ono lepiej zbadane (Hulten 1950);

c. znalezieniem czterokrotnych kwiatów także na okazach $C$. pumiulm subsp. pallens, co zaznaczono wyróżniając okazy o pewnym procencie kwiatów czterokrotnych jako nową formę ( $f$. subtetrandroides Zaj.). 